\title{
Dik ve Yatay Kuyuların Tight Gaz Kondensat Rezervuarında Kuru Gaz Enjeksiyonlu ve Enjeksiyonsuz Üretim Performanslarının Karşılaştırılması
}

\author{
Production Performance Comparison of Vertical and \\ Horizontal Wells in Tight Gas Condensate Reservoir with \\ and without Dry Gas Injection
}

\author{
Can Polat ${ }^{*}$ (I) , Tuna Eren 2 (D)
}

${ }^{1}$ Petroleum and Natural Gas Engineering Department, Izmir Katip Celebi University, Cigli Ana Yerleskesi, Merkezi Ofisler Binasi, 35620, Cigli, Izmir, Turkey

${ }^{2}$ Eni International Resources Limited, Ankara, Turkey

Sorumlu Yazar / Corresponding Author*: can.polat@ikcu.edu.tr

Atıf sekli/ How to cite: POLAT, C., EREN, T. (2020). Production Performance Comparison of Vertical and Horizontal Wells in Tight Gas Condensate Reservoir with and without Dry Gas Injection. DEUFMD, 23(67), 339-348.

Öz

$\mathrm{Bu}$ çalışmada, bir tight gaz kondensat rezervuarı için dik ve yatay üretim kuyularının bulunduğu senaryolarla kuru gaz enjeksiyonunun etkilerinin karşılaştırılması bir rezervuar simülasyon çalışması ile gerçekleştirilmiștir. Bu çalışmanın yürütülmesi için bir rezervuar kesiti tanımlanmıştır. Seçilen rezervuar alanı 420x420 m genişliğinde ve $50 \mathrm{~m}$ kalınlığındadır. Rezervuar kaya özelliklerinin tamamı ve rezervuar akıșkan bileșimleri ile birlikte akıșkan spesifikasyonları literatürde mevcut olan veriler dikkate alınarak belirlenmiştir. Bu çalışmanın gerçekleștirilmesi için profesyonel bir rezervuar simülasyon bilgisayar programı kullanılmıștır. Kuyuların yörüngeleri özel bir sondaj ve tamamlama çalıșması neticesinde belirlenmiștir. Çalıșma, gaz kondensat rezervuarlarında petrol sıvılaşmasını engellemede kuru gazın etkili bir biçimde yatay kuyuların drenaj bölgelerine ulaşmasından ötürü yatay kuyuların dik kuyularla karşılaștırıldığında daha etkin olduğunu kanıtlamıştır. Literatür, yatay kuyuların gaz kondensat rezervuarlarında sıvı petrol yoğunlașmasının gecikmesinin etkisi üzerine araștırmalar içermektedir. Bu araștırma kuru gaz enjeksiyonu sırasında dikey ve yatay kuyuların kuyu performansının karșılaștırılmasıyla ilgili literatürdeki boşluğu doldurmak amacıyla gerçekleștirilmiştir.

Anahtar Kelimeler: rezervuar mühendisliği, sondaj mühendisliği, gaz kondensat rezervuar, yatay kuyular, rezervuar simülasyonu

Abstract

In this study, the comparison of dry gas injection for vertical and horizontal production well scenarios are investigated by means of conducting a reservoir simulation study for a tight condensate gas reservoir. In order to conduct this study a reservoir pattern has been defined. The selected reservoir pattern is $420 \times 420 \mathrm{~m}$ in areal extend and $50 \mathrm{~m}$ in thickness. All of the necessary reservoir rock properties, and fluid specifications together with reservoir fluid compositions have been determined considering the data available in the literature. A professional reservoir simulation computer program has been utilized for the realization of this study. The well directional 
trajectories are determined through a dedicated drilling and completion study. The study proved that horizontal wells are much effective in drainage mechanisms in comparison to vertical wells by the fact that dry gas being able to efficiently reach to horizontal drain sections to prevent condensation of oil in the formation for gas condensate reservoirs. The literature contains research on influence of horizontal well on the retardation of the oil condensation inside the gas condensate reservoirs. This research study is conducted to fill the gap in literature in relation to comparison of the well performance of the vertical and horizontal wells during the dry gas injection.

Keywords: reservoir engineering, drilling engineering, gas condensate reservoirs, horizontal wells, reservoir simulation

\section{Introduction}

The objective of this study is to simulate a tight gas reservoir with gas condensate. Condensate is the liquid produced from retrograde gas reservoirs [1]. It is widely known that retrograde condensation is defined as the formation of liquid that can be obtained by an isothermal decrease in pressure [2], as depicted in Figure 1.

Initially the well profiles for vertical and horizontal wells were defined in the scope of drilling and well completion engineering. Then the reservoir specifications were determined, the well profiles for vertical and horizontal types are input into the reservoir simulation package. In this study the reservoir simulation computer package program CMG (GEM Simulation) 2018.10.6863.39860 has been used [3].

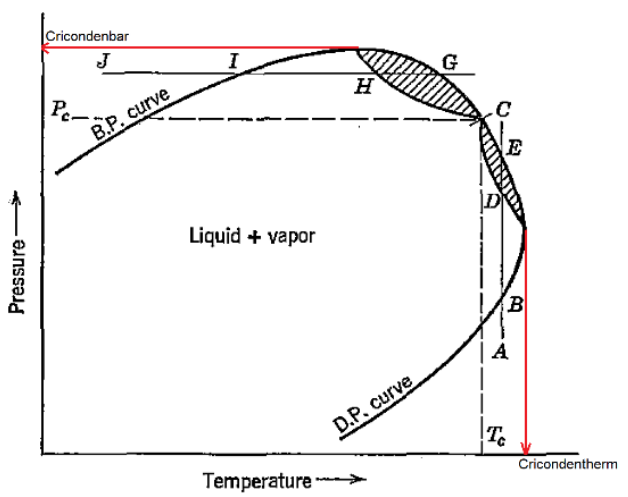

Figure 1. Pressure-Temperature diagram for a retrograde system (inspired from [2]).

\section{Literature Review}

The temperature of the gas condensate reservoirs lies between critical temperature $\left(\mathrm{T}_{\mathrm{c}}\right)$ and cricondentherm of the phase diagram of the reservoir fluid [1], [4] as in Figure 1. In the circumstance of reservoir pressure exceeding the dew point pressure, oil phase does not exist in the reservoir. Isothermal depletion (line EA in Figure 1) of the reservoir causes the reservoir pressure to fall below the dew point [1], [4]. Condensation of the liquid phase occurs at this stage. It can be deducted from the phase diagram that further reservoir pressure depletion might lead to the revaporization of the condensed liquid [1], [4]. However, the phase envelope tends to move downwards and to the right as a result of the overall composition change during the condensation [1], [4]. Hence, re-vaporisation is restrained [1], [4].

Condensation of the liquid phase during the depletion of the reservoir and re-vaporization of this condensed liquid are the two events unique to gas condensate reservoirs [5]. The condensed liquid phase involves the most valuable parts of the hydrocarbon mixture [6]. It is highly difficult to produce these valuable components once they are precipitated in the reservoir [6]. The methods that can be beneficial for re-vaporization of the condensed components are limited [7] and condensed liquid phase is mostly immobile as the critical saturation required for mobilization of this liquid phase is rarely approachable [4]. Moreover, it can be highly viscous as it is basically comprised of the heavy components. Besides, the phenomena of liquid condensation results in reduction in the gas relative permeability, which adversely affect the gas recovery [6],[7]. The adverse effect of the condensate is excessive in tight gas reservoirs [8] and especially nearby the production wells where pressure depletion is the highest. The development of condensate blockage nearby the production wells can be considered as an additional skin [9].

Pressure maintenance, vaporization of the condensate components and wettability alteration are the considered methods to control the condensation in the reservoir 
[9],[10]. In this regard, there are various suggested techniques such as drilling horizontal wells, hydraulic fracturing before and after the formation of condensate bank, acidizing after the formation of condensate bank and dry gas injection for reducing the condensate amount in the reservoir [11],[12]. Gas can be recycled from the commencing of the production process and mostly it is more efficient than the delayed gas recycling method [13]. It should be noted that injection of the produced dry gas negatively affects the gas recovery factor as the injection process results in the loss of dry gas that would be otherwise produced.

There are studies proving the positive effect of horizontal wells on retardation of liquid condensation in comparison to the vertical wells [12],[14]. However, the distribution and functionality of the dry gas components will be different in these two cases. Thus, it is also needed to evaluate and compare the performance of vertical and horizontal wells during the dry gas injection.

\section{Well Planning}

Today most of the wells are being drilled directionally [15]. The drilling planning for this reservoir simulation study is composed of twofold. The first lot of drilling engineering study was composed of the planning of the vertical wells for the first two scenarios. The second part was composed of the planning of the horizontal wells for the scenarios 3-4. The well plan views are as depicted in Figure 2.

The vertical well is planned considering the field practices for drilling and well completion engineering. Figure 3 depicts the scaled vertical well sketch.

Table 1 gives the planned trajectory for an horizontal well. The necessary inputs in order to plan for an horizontal well, one needs to know the setting depth of the casing, the status of the problematic formations, and the requirements for the wellbore stability aspects. For instance, for the horizontal well in subject which is Well-1Hor in Figure 2 (b); a well trajectory that is cruising to $180^{\circ} \mathrm{Azm}$. Horizontal displacement is calculated on the basis of segment course. For instance, if the segment of the wellbore trajectory is vertical, the horizontal displacement will not be any different. For instance, it can be recognized that for Well-1Hor the Kick of Point (KOP) is at 800 $\mathrm{m}$. That means the well is started to be directionally drilled starting from $800 \mathrm{~m}$. Then the trajectory is built with a build rate or Dog Leg Severity (DLS) of $3 \% / 30 \mathrm{~m}$, until the wellbore deviation angle is $35^{\circ}$ at the End of Build (EOB). This angle of deviation is selected because at the respective hole size ranges, the downhole equipment can easily achieve this aforementioned deviation. Here at this point the segment of the wellbore is designed to have a radius of $573 \mathrm{~m}$, which means that if the wellbore inclination was set to reach $90^{\circ}$ from vertical, the horizontal displacement was going to be $573 \mathrm{~m}$ in magnitude.

$R=\frac{360}{2 \pi} \frac{\Delta L}{\Delta i}$

where, $\mathrm{R}$ is radius of curvature in $\mathrm{m}, \Delta \mathrm{L}$ is change of course in $\mathrm{m}$, and $\Delta \mathrm{i}$ is the change in angle.

Table 1. Horizontal well planned trajectory.

\begin{tabular}{|c|c|c|c|c|c|c|c|c|c|c|c|}
\hline Section & MD, $m$ & $\begin{array}{l}\text { Inc, } \\
\text { deg }\end{array}$ & $\begin{array}{l}\text { Azm, } \\
\text { deg }\end{array}$ & $\begin{array}{l}\Delta H o r \\
\text { Disp, } \\
\text { m }\end{array}$ & $\Delta \mathrm{Z}, \mathrm{m}$ & $\Delta \mathrm{N}, \mathrm{m}$ & $\Delta \mathrm{E}, \mathrm{m}$ & $\mathrm{Z}, \mathrm{m}$ & $\mathrm{N}, \mathrm{m}$ & $\begin{array}{l}\mathrm{E}, \\
\mathrm{m}\end{array}$ & $\begin{array}{l}\text { Hor } \\
\text { Disp, } \\
\text { m }\end{array}$ \\
\hline $\mathrm{n}$ & 0 & 0 & 180 & 0 & 0 & 0 & 0 & 0 & 1770.199 & 0.5 & 0 \\
\hline KOP & 800 & 0 & 180 & 0 & 800 & 0 & 0 & 800 & 1770.199 & 0.5 & 0 \\
\hline $\mathrm{EOB}$ & 1150 & 35 & 180 & 104 & 328.6351 & -103.618 & $1.27 \mathrm{E}-14$ & 1128.635 & 1666.58 & 0.5 & 104 \\
\hline HOLD & 3442.765 & 35 & 180 & 1315 & 1878.123 & -1315.08 & $1.61 \mathrm{E}-13$ & 3006.758 & 351.5047 & 0.5 & 1419 \\
\hline EOB & 3855.265 & 90 & 180 & 352 & 183.242 & -352.005 & $4.31 \mathrm{E}-14$ & 3190 & -0.5 & 0.5 & 1771 \\
\hline EOT & 4274.265 & 90 & 180 & 419 & $2.57 \mathrm{E}-14$ & -419 & $5.13 \mathrm{E}-14$ & 3190 & -419.5 & 0.5 & 2190 \\
\hline
\end{tabular}


Once the trajectory is at an angle of $35^{\circ}$, the trajectory is set to hold for a course of $2293 \mathrm{~m}$. This interval of hold is selected so that the horizontal well's trajectory is at a depth of 3006 $m$ TVD. The selected depths are based on drilling practices considering the behaviour of formations.

In the successive well trajectory section, the wellbore is set to be built again to reach to an angle of $90^{\circ}$ which is an angle that is complete horizontal from vertical. The build rate at this stage is selected to be $4^{\circ} / 30 \mathrm{~m}$. The angle at the EOB for this section is $90^{\circ}$ Once the horizontal angle is reached the successive step is to drill the drain section which is set for $419 \mathrm{~m}$ in terms of length. Figure 4 depicts the trajectory layout (as unscaled) of the horizontal well.

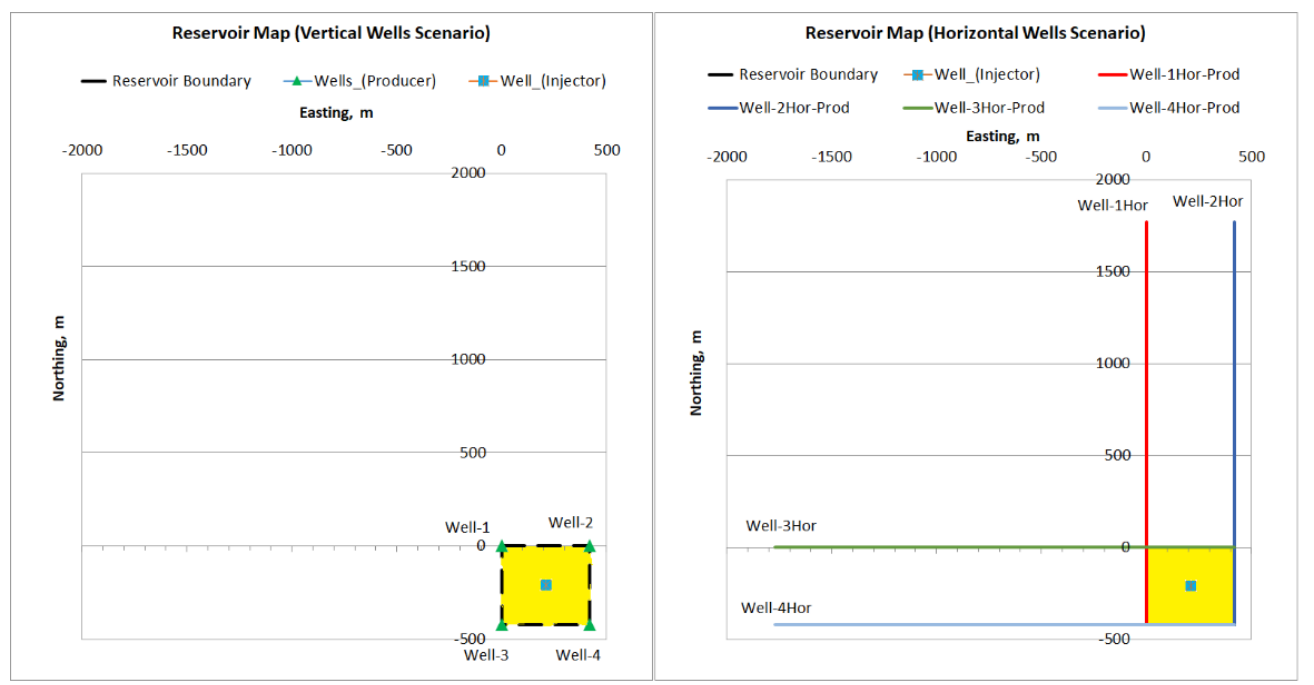

Figure 2. Well plan views (a) vertical wells, and (b) horizontal wells.

\section{Methodology of the Research}

The methodology of the modelling work that is studied is presented in this section. Figure $\mathbf{5}$ depicts the methodology for the reservoir model construction. The first step is the construction of the reservoir structure. The selected reservoir's areal extend is $420 \times 420 \mathrm{~m}$, and thickness is $50 \mathrm{~m}$. The selected pattern definitions are in line with the estimates of optimal well spacing presented by Zoback and Kohli (2019) [16]. The size of the grids, the grid numbers together with the layers are defined in this step. For this specific study the determined grid number is 27 in both $\mathrm{x}$ and $\mathrm{y}$ directions. The corner grids which include the vertical production wells in scenario- 1 and scenario-2 are sized as $1 \times 1 \mathrm{~m}$. The more the longer the distance from the production wells the sizes of the grids increase. The largest grid is sized as
$20 \times 20 \mathrm{~m}$. The model consists of 5 layers each with a thickness of $10 \mathrm{~m}$.

Reservoir rock and fluid structuring is the next step in the model construction. Depths, porosity, permeability, saturations, compositions, pressures and temperature magnitudes are input at this step. The reservoir and fluid characteristics are input as per the tabulated information presented in Table 2 . Permeability and porosity properties are structured based on the properties of a tight gas reservoir, presented in the study of Becker et al., [17]. Initial reservoir gas composition is adapted from the study of Nagarajan et. al., [18].

Component definitions are made within the simulator for the hydrocarbon and $\mathrm{CO}_{2}$ content. The specifications such as critical pressure $\left(\mathrm{P}_{c}\right)$, temperature, acentric factor is determined at this step. 


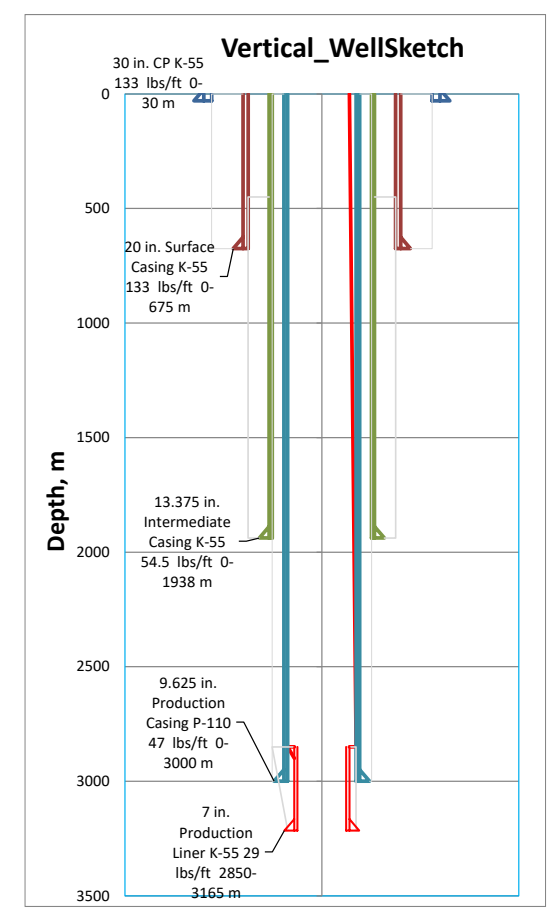

Figure 3. Vertical well sketch (scaled drawing).

Horizontal Well-Sketch

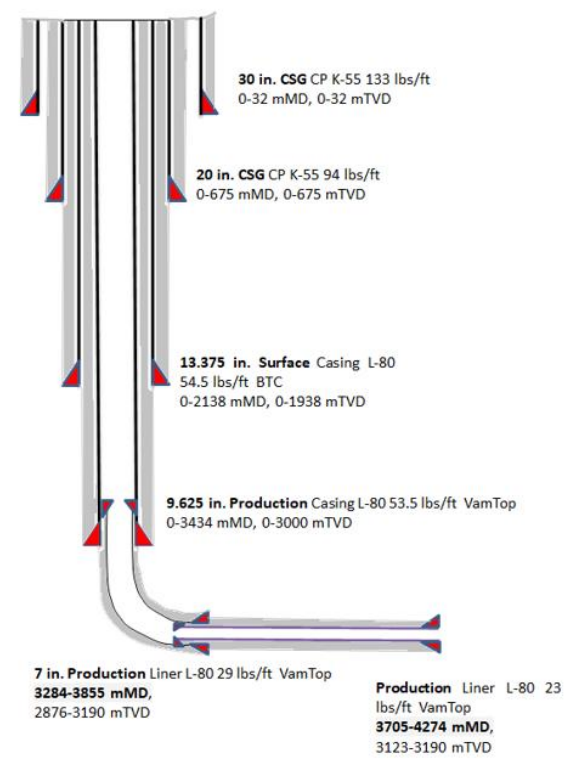

Figure 4. Horizontal well sketch (unscaled drawing).

The successive step in the reservoir simulation methodology is the reservoir rock type input. At this step relative permeability, and capillary pressure are specified. Figure 3, depicts oil and gas relative permeability versus gas saturation, inspired from [18], [19]. The relative permeability values between the gas saturation $0.40-0.75$ are utilized. Initial gas saturation has a value of 0.75 . Following the evolution of the condensate within the reservoir as a result of the reduction in reservoir pressure, the gas saturation decreased to final magnitudes in the neighbourhood of 0.40 . Capillary pressure between water and oil is neglected, because the water that is in the reservoir is immobile connate water. This phenomenon of neglecting the capillary pressure is achieved by means of defining a capillary pressure between water and oil as a null value. The capillary pressure between the gas and the oil is also neglected because, interfacial tension in between the two phases is at negligible magnitudes.

The well trajectories are input in to the simulator as per the drilling study conducted. The planned trajectories for the vertical and horizontal wells are defined accordingly so that the reservoir simulation study can be conducted.

For well completion input, the sections of the wellbores which cross the grids are taken into consideration.

The well constraints are determined considering practical conditions valid in oil/gas fields. The gas production rate is taken as 3300 $\mathrm{sm}^{3} /$ day for each well. Bottom hole pressure values for producing wells are taken as 1500 $\mathrm{kPa}$ as a minimum. The gas injection rate is taken as $3000 \mathrm{sm}^{3} /$ day.

Figure 7 depicts the four scenarios for the reservoir simulation. In scenario-1 the area is simulated with no injection and four vertical wells at the corners of the reservoir pattern. Scenario-2 is with injection from the centre of the patterns, and four vertical producers at the corners of the reservoir pattern. In order to see the effect of gas injection into the gas condensate production these two scenarios are included in the simulation study.

For scenario-3 the reservoir in subject is simulated again with no injection, but this time with four horizontal wells surrounding the developed pattern having their drain sections at $3190 \mathrm{~m}$. The last scenario is investigated with injection of dry gas from the centre point of the 
DEÜ FMD 23(67), 339-348, 2021

patterns and four horizontal producing wells important to highlight at this point is that the surrounding the pattern at each side. It is injector wells are vertical.

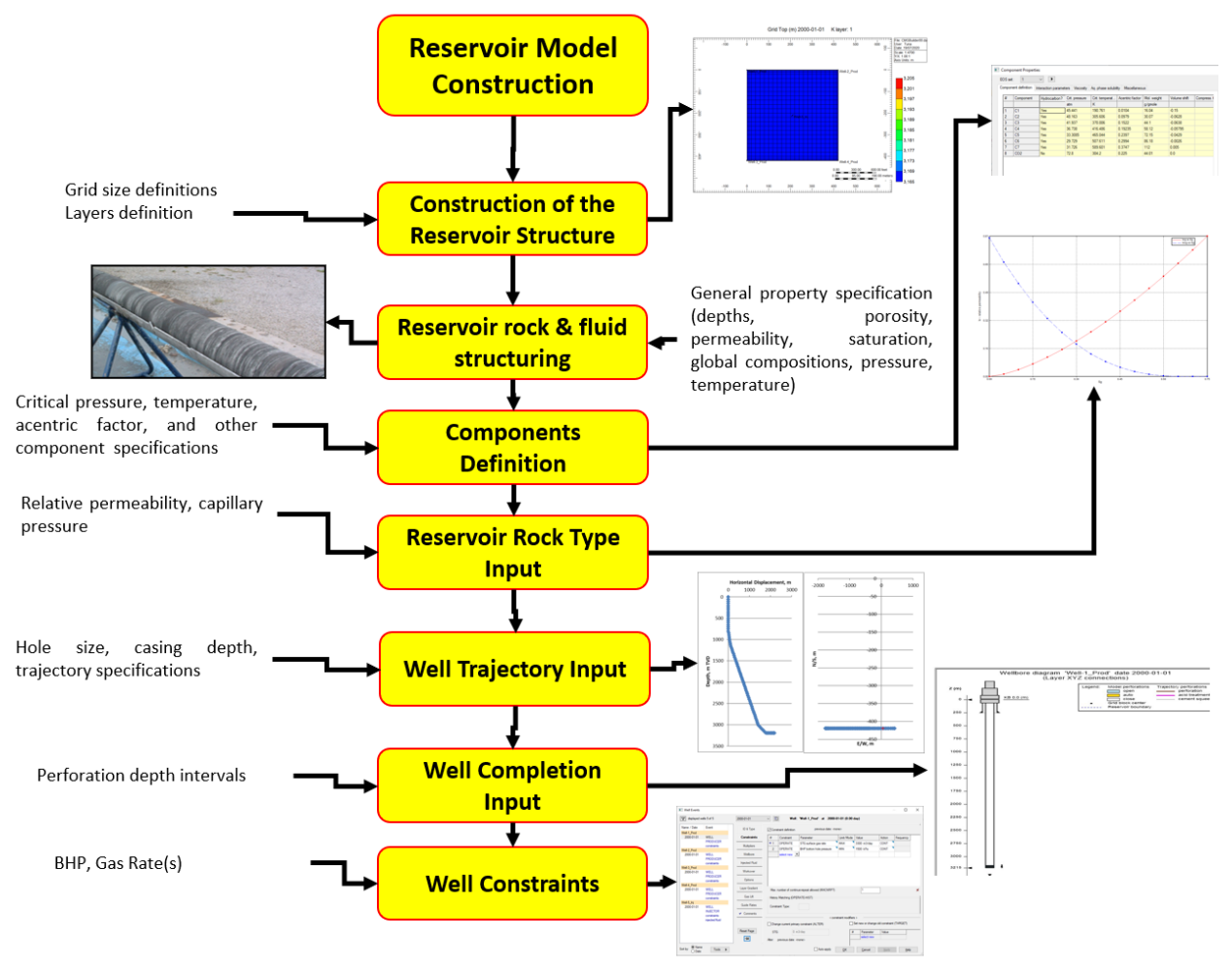

Figure 5. The methodology for reservoir model construction.

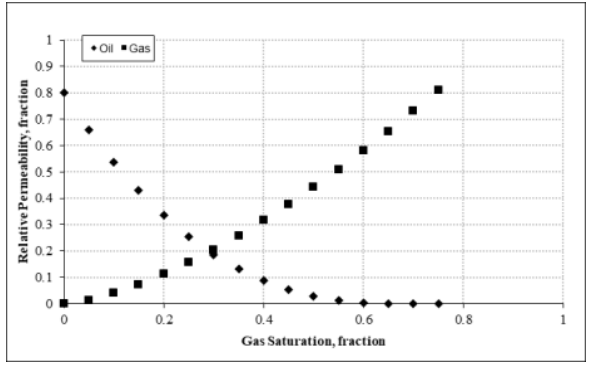

Figure 6. Relative permeability versus gas saturation chart for oil and gas simulated in the study.
Table 2. Reservoir and Fluid Characteristics.

\begin{tabular}{|l|r|}
\hline Reservoir description and physical properties & \\
\hline Reservoir top, $\mathrm{m}$ & 3165 \\
\hline Reservoir thickness, $\mathrm{m}$ & 50 \\
\hline Initial average reservoir pressure, $\mathrm{kPa}$ & 32000 \\
\hline Reservoir temperature, ${ }^{\circ} \mathrm{C}$ & 113 \\
\hline Porosity, \% & 13 \\
\hline System permeability, $\mathrm{md}$ & 0.1 \\
\hline Initial water saturation, $\%$ & 25 \\
\hline Fluid Properties & \\
\hline Initial gas density, $\mathrm{kg} / \mathrm{m} 3$ & 329.028 \\
\hline Initial gas viscosity, cp & 0.039 \\
\hline Initial GOR, sm3/sm3 & 1794 \\
\hline Reserve Data & \\
\hline Original Oil in Place, In Oil Zone, sm3 \\
\hline Original Oil in Place, Condensate in Gas Zone, sm3 & 112897 \\
\hline Original Gas in Place, OGIP, sm3 & 202519000 \\
\hline
\end{tabular}

The reservoir and fluid characteristics are as given in Table 2. The reservoir top is at $3165 \mathrm{~m}$. The reservoir is deep enough to ensure that gas injection can be safely realized. Originally there 
is no oil inside the reservoir, because the initial reservoir pressure is above the dew point pressure. The simulation calculation revealed that about $113000 \mathrm{sm}^{3}$ of condensate oil is dissolved within the reservoir gas solution.

The composition of the injected dry gas is as tabulated in Table 3 . The tabulated composition for the injection dry gas is derived from the produced gas specifications given by the simulator. The given composition specifications indicate that the gas injected is dry in its nature as it can be attributed to the high fraction of $\mathrm{C} 1$ component, as well as having relatively low mole fractions for heavier components.

Table 3. Composition of the dry gas injected.

\begin{tabular}{|l|r|}
\hline Component & Mole Fraction \\
\hline CO2 & 0.011 \\
\hline C1 & 0.77 \\
\hline C2 & 0.11 \\
\hline C3 & 0.053 \\
\hline C4 & 0.02 \\
\hline C5 & 0.02 \\
\hline C6 & 0.007 \\
\hline C7+ & 0.009 \\
\hline
\end{tabular}

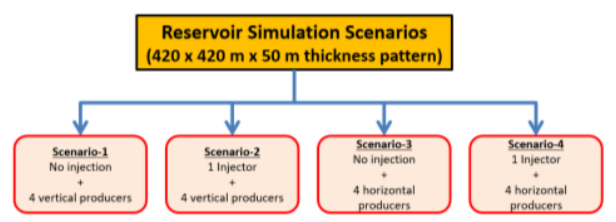

Figure 7. Reservoir simulation scenarios.

\section{Results and Discussion}

In this section, the results of the reservoir simulation study are elaborated. Figure 8 depicts the gas production rate versus time for all of the four scenarios studied in the scope of the research project. For all scenarios, the gas production rates are constant for certain duration of time span. However, as the bottom hole pressures for the producer wells reach to the bottom hole pressure constraint, the gas production rates commence to decrease, Figure 9. It is observed that for the vertical well cases (scenario-1 and scenario-2) the gas production rates commence to decrease drastically much earlier than the horizontal well cases (scenario3 and scenario-4). This is attributed to the fact that the horizontal wells provide much more efficient reservoir drainage. Another important observation is the delay of the gas production decrease with the dry gas injection scenarios in reference to no-injection scenarios.

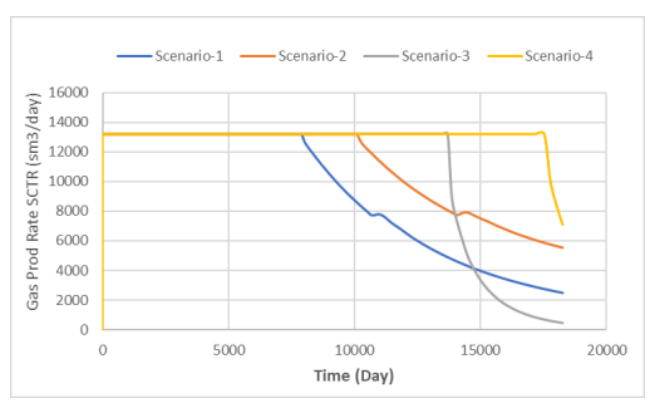

Figure 8. Gas production rate versus time.

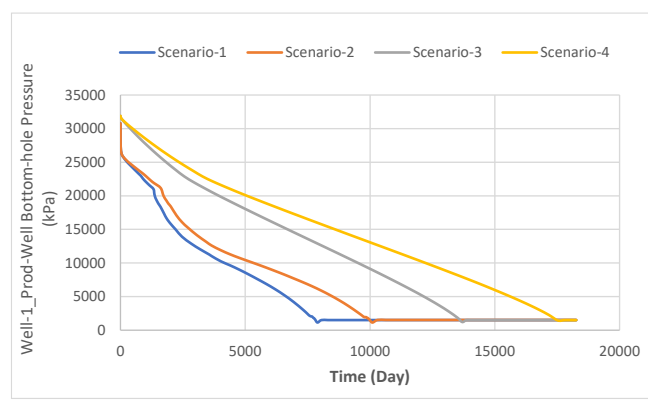

Figure 9. Production well bottom hole pressure versus time (Well-1).

Initially, the oil production rates are same and constant for all scenarios as shown in Figure 10. This is because there is no liquid condensation inside the reservoir, and gas production rates are the same as in Figure 8. However, as time progresses, due to the reduction in pressure and dry gas injection conditions, the oil production rates show different responses. For example, the greatest oil production rate is achieved in scenario- 4 due to the horizontal wells utilization (hence having higher well bottom hole pressures) and dry gas injection. It is noted that oil production rates in scenario- 2 are greater than the oil production rates in scenario-3, although the bottom hole pressures in scemari-3 are greater than scenario-2. This reveals the importance of dry gas injection as in scenario-2. The sudden increases in scenario- 3 and scenario- 4 are due to the sudden re-vaporization of the oil phase inside the reservoir. This sudden peak in oil production rate is not observed in the vertical well scenarios. This fact is due to the 
composition of the fluids inside the reservoir during the occurrence of condensation.

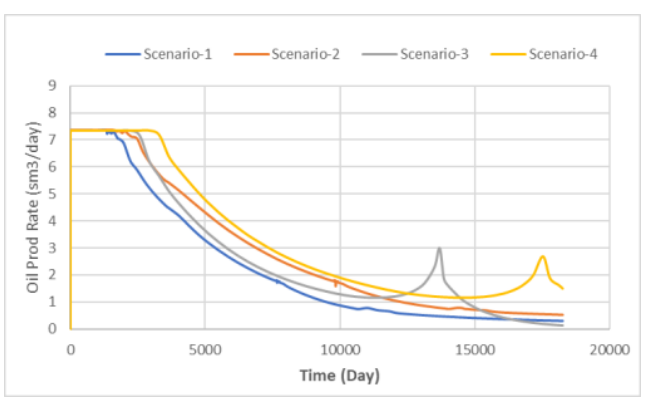

Figure 10. Oil production rate versus time.

The gas oil ratio for all scenarios is as depicted in Figure 11. In line with the comments given above the lowest gas-oil ratio that is observed in early times is in scenario-4. As mentioned during the specific period up to circa 10000 days, in which the gas production rates are same, the oil production rate is highest in scenario-4. The sudden reductions in gas-oil ratio for scenario- 3 and scenario- 4 are related to the sudden increases in oil production of the same scenarios. At this point it is important to highlight that the horizontal wells contribute to reservoir development with the advantage of large re-vaporization of the condensed liquids back into the light component structures.

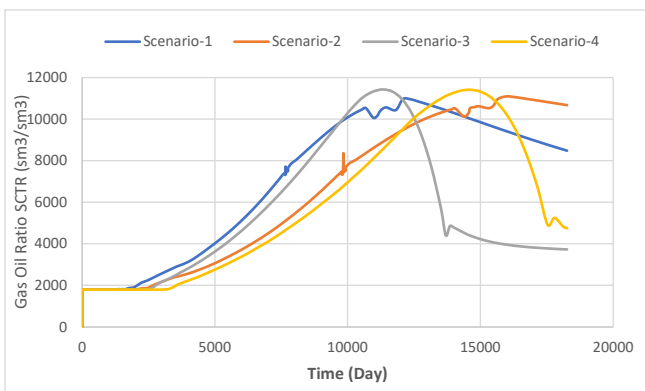

Figure 11. Gas oil ratio versus time.

The transformation of the heavier components $(\mathrm{C} 7+)$ into gas phase and the transformation of light components into oil phase during dry gas injection can be inferred by comparisons of the scenarios with and without gas injection; as depicted in oil mole fractions versus time graphs for $\mathrm{C} 7+$ and $\mathrm{C} 1$ components, Figure $\mathbf{1 2}$ and Figure 13.

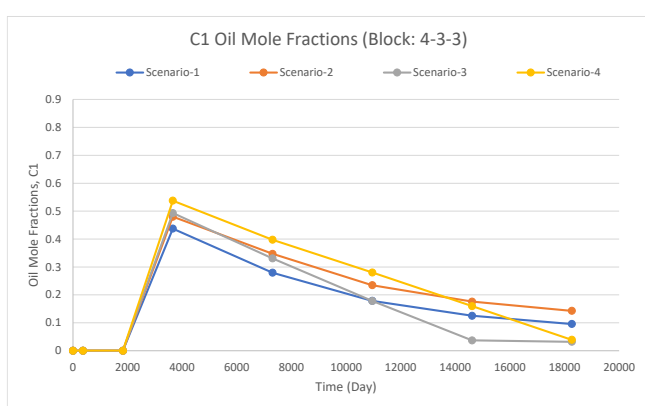

Figure 12. C1 oil mole fractions versus time for Block 4-3-3.

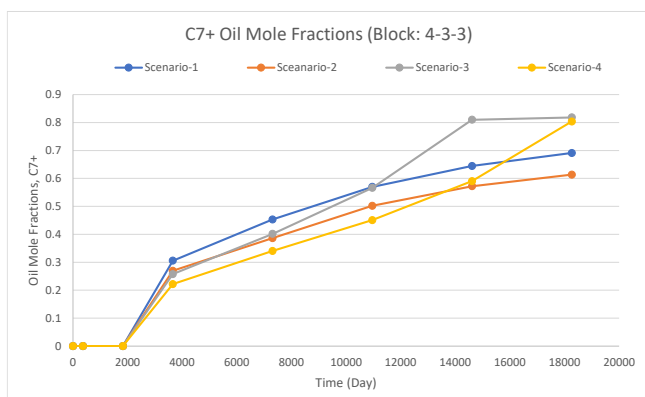

Figure 13. $\mathrm{C} 7+$ oil mole fractions versus time for Block 4-3-3.

Gas recovery factor versus time is depicted in Figure 14. It is observed that when the wells to develop the field are selected to be horizontal, the gas recovery factors are superior to the case of vertical development wells. In cases of dry gas injection, the overall gas recovery is reduced. This phenomenon is due to the fact that the injected dry gas is decomposed in the reservoir, assisting the re-vaporization of the heavier components for recovery.

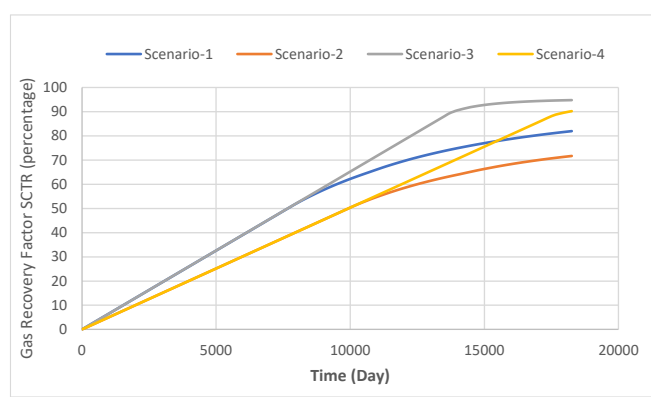

Figure 14. Gas recovery factor versus time for all scenarios.

Oil recovery versus time is as shown in Figure 15. The greatest oil recovery is with the horizontal wells which are used to develop the 
field with injection, scenario-4. Scenario-2 on the other hand, is the second highest oil recovery scenario. When scenario-1 and scenario-3 are compared to one another, the influence of higher pressures nearby the production wells in the case of horizontal wells results in having less condensate evolution inside the reservoir, and that is why the oil recovery factor for scenario-3 is more than that of scenario-1. Although in scenario-2 the bottom hole pressures are observed to be less than the bottom hole pressure of scenario-3, the recovery factor in scenario- 2 is more than the recovery factor in scenario-3, due to dry gas

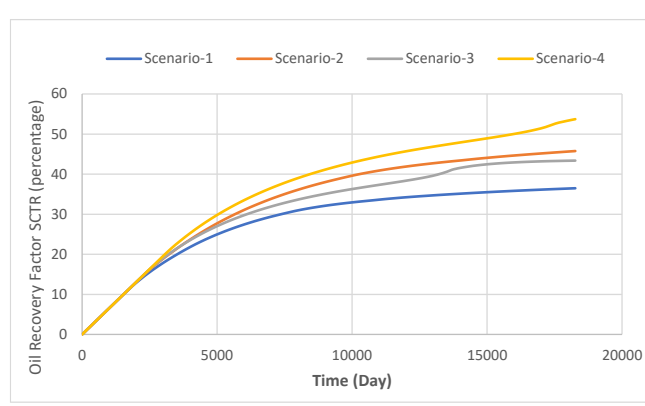

Figure 15. Oil recovery factor versus time for all scenarios. influence on the component transformation.

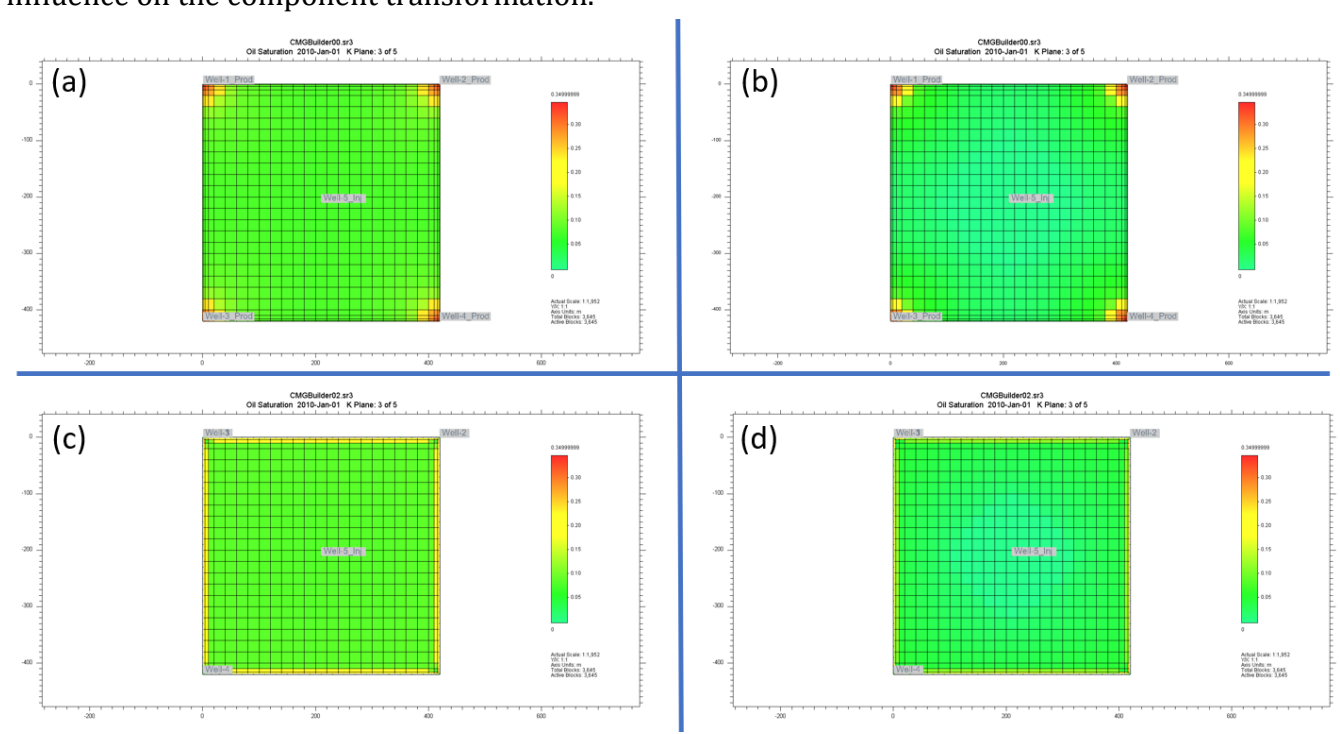

Figure 16. Oil saturation distribution for all scenarios at time 3653 days (10 years); (a) scenario-1, (b) scenario-2, (c) scenario-3, (d) scenario-4.

Figure 16 presents the oil saturation distribution in layer-3 for all scenarios at time 10 years. It is important to mention that horizontal wells are designed to be present along layer-3. For scenario-1 and scenario-2 at the immediate vicinity of vertical wells, the oil saturation colouring indicates that there exists an intense oil saturation nearby the production wells. The condensation of the oil nearby the vertical wellbores, results in additional pressure loss nearby the wellbore, resulting in production restriction. However, for scenario-3 and scenario-4 even though the oil condensation is evident near the wellbore vicinity, the order of magnitude for the condensation is not as much high as it is the case for the vertical wells' scenarios (e.g. scenario-1 and scenario-2). The benefit of this phenomenon is a production that is not restricted as compared to the latter cases. It is also observed that in scenario-4 the injected dry gas has much efficiently reached to the horizontal drain sections of the wells, and resulted in having a much lower condensed oil situation (for scenario-4) in comparison to the vertical wells with injection case (scenario-2). This is a proof of the ability for horizontal wells in having a much effective drainage mechanism.

\section{Conclusions}

In order to realize the reservoir simulation study in retrograde gas reservoirs, a pattern of 


\section{DEÜ FMD 23(67), 339-348, 2021}

reservoir areal extend with a thickness of $50 \mathrm{~m}$ has been defined. The four scenarios include different production well profiles in common, namely vertical and horizontal well profiles. The horizontal well trajectory is determined considering the drilling and completion engineering field practices.

Dry gas injection revealed that with the injection of light components (e.g. the major components of dry gas) the component transformation inside the reservoir takes place and the liquid components are transformed into the gas phase.

Dry gas injection has had a greater influence on bottom hole pressures in horizontal well cases in reference to vertical well cases. This shows that with horizontal wells, the amount of injected gas to reach to the production wells is much greater.

Oil production has benefited from the utilization of horizontal wells by sudden production rate jumps, which has not been noticed in vertical well cases. This phenomenon is attributed to a fact related to composition mechanism taking place inside the reservoir.

Component transformation in between the condensate and gas phase is another benefit that has been noticed due to the dry gas injection, which resulted to further production of heavier (C7+ and alike) components.

\section{Acknowledgements}

Both authors are thankful to Computer Modelling Group LTD. for providing the academic version of the CMG (GEM) software for reservoir engineering simulation used in the research study.

\section{References}

[1] McCain Jr, W. D. 1990. Properties of petroleum fluids. PennWell Corporation, Tulsa, OK, 548.

[2] Burcik, E.J. 1979. Properties of Petroleum Reservoir Fluids. International Human Resources Development Corporation, Boston, 190.

[3] CMG, 2019. GEM. https://www.cmgl.ca/gem (Accessed 19.07.2020).

[4] Dake, L.P. 1983. Fundamentals of Reservoir Engineering. Elsevier, The Netherlands, 437.

[5] Raghavan, R., Jones, J. R. 1996. Depletion performance of gas-condensate reservoirs, Journa of Petroleum, Vol. 48(8), pp. 725-731. DOI: https://doi.org/ 10.2118/36352-JPT

[6] Thomas, F.B., Holowach, N., Zhou, X. and Bennion, D.B. 1994. Optimizing production from gas condensate reservoirs. Annual Technical Meeting, 12-15 June, Calgary, Alberta, 1-14.

[7] Ahmed, T Evans, J. Kwan, R and Vivian, T. 1998. Wellbore liquid blockage in gas-condensate reservoirs. SPE Eastern Regional Meeting, 9-11 November, Pittsburgh, Pennsylvania, 1-11.

[8] Thomas, F.B., Zhou, X., Bennion, D.B. and Bennion, D.W. 1995. Towards optimizing gas condensate reservoirs. Annual Technical Meeting, 7-9 June, Calgary, Alberta, 1-18.

[9] Cvetkovic, B., Economides, M.J., Omrcen, B. and Longaric, B. 1990. Production from Heavy Gas Condensate Reservoirs. European Petroleum Conference, 21-24 October, The Hague, Netherlands, 1-7.

[10] Izuwa, N.C., Obah, B. and Appah, D. 2014. Optimal gas production design in gas condensate reservoir. Nigeria Annual International Conference and Exhibition, 5-7 August, Lagos, Nigeria, 1-18.

[11] Miller, N., Nasrabadi, H. and Zhu, D. 2010. On application of horizontal wells to reduce condensate blockage in gas condensate reservoirs. International Oil and Gas Conference and Exhibition in China, 810 June, Beijing, China, 1-15.

[12] Hashemi, A. and Gringarten, A.C. 2005. Comparison of Well Productivity between Vertical, Horizontal and Hydraulically Fractured Wells in GasCondensate Reservoirs. SPE Europec/EAGE Annual Conference, 13-16 June, Madrid, Spain, 1-15.

[13] Hernandez, I., Ali, S.M. and Bentsen, R.G. 1999. First steps for developing an improved recovery method for a gas condensate reservoir. Annual Technical Meeting, June 14 - 18, Calgary, Alberta, 1-15.

[14] Miller, N., Nasrabadi, H. and Zhu, D. 2010. On application of horizontal wells to reduce condensate blockage in gas condensate reservoirs. International Oil and Gas Conference and Exhibition in China, 810 June, Beijing, China, 1-15.

[15] Eren T., Suicmez V.S. 2020. Directional Drilling Positioning Calculations, Journal of Natural Gas Science and Engineering, Vol. 73(103081), pp. 1-24. DOI: https://doi.org/ 10.1016/i.jngse.2019.103081

[16] Zoback, M.D., Kohli, A.H. 2019. Unconventional reservoir geomechanics. Cambridge University Press, United Kingdom, 483.

[17] Becker, I., Wüstefeld, P., Koehrer, B., Felder, M., Hilgers, C. 2017. Porosity and permeability variations in a tight gas sandstone reservoir analogue, Westphalian D, Lower Saxony Basin, NW Germany, Journal of Petroleum Geology, Vol. 40(4), $\mathrm{pp}$. https://doi.org/10.1111/ipg.12685

[18] Nagarajan, N. R., Honarpour, M. M., Sampath, K., McMichael, D. 2004. Comparison of Gas-Condensate Relative Permeability Using Live Fluid vs. Model Fluids. International Symposium of the Society of Core Analysts, 5-9 October, Abu Dhabi, 1-13.

[19] Jamiolahmady, M., Danesh, A., Tehrani, D. H., \& Duncan, D. B. 2003. Positive effect of flow velocity on gas-condensate relative permeability: network modelling and comparison with experimental results, Transport in Porous Media, Vol. 52(2), pp. 159-183. DOI: https://doi.org/ 10.1023/A:1023529300395 